\title{
AN INDIVIDUAL'S COGNITIVE ACTIVITY PROBLEM IN HISTORY RETROSPECTIVE
}

\author{
Inna Zaitseva ${ }^{1}$, Tetiana Pashchenko², Petro Luzan ${ }^{3}$,
}

$1 \mathrm{PhD}$ in Pedagogy, docent of the Department of Journalism, Ukrainian philology and culture University of the State Fiscal Service of kraine

http://orcid.org/0000-0002-4149-2916

e-mail: zivia@ukr.net

$2 \mathrm{PhD}$ in Technicals, Senior researcher, Senior researcher at the Laboratory for scientific-methodological support of specialists training in colleges and technical schools Institute of VET of NAES of Ukraine http://orcid.org/0000-0002-7629-7870 e-mail: tantarena@ukr.net

3 DSc in Education, Professor Principal researcher Laboratory for scientific-methodological support of specialists training in colleges and technical schools Institute of vocational education and training of NAES of Ukraine http://orcid.org/0000-0002-8853-9275 e-mail: petr.luzan@ukr.net

\begin{abstract}
Abstarct. The article studies the aspects of cognitive activity and the activity in history retrospection.
The cognition and its study is not something unchanged, once and for all given, but is something that develops under certain laws. It has long history with the sources in the most ancient philosophy. At every stage of its development the knowledge is the result of the history of knowledge, the essence of all human activity forms.

Scientific knowledge has its historically altered morphology. Its historical path analysis makes it possible to argue its origin from ancient philosophical schools, philosophers of Ancient India, China, Egypt, the countries of Mesopotamia.

The phenomenon of an individual's cognitive activity is complex and multifaceted. Scientists argue that cognitive activity is a complicated process of transition from ignorance to knowledge, from inability to ability, from random observations to systematic knowledge of the material world, to mastering the scientific truths. At the same time, a man, mastering new knowledge, affects the world, which, in turn, changes human life.

The article analyses the influence of historical conditions on developing scientific thought about cognition, cognitive activity.

The effectiveness of studying students' educational and cognitive activity depends on how thoroughly the cognitive process is studied and the way its laws and features are used. The authors emphasise that taking into account the cognition theory possibilities, its Klondike was set in the Ancient world era and filled with new content rising to a new level in each generation, allows predicting the problem studying vector and put forward the hypothetical predictions of its solution.
\end{abstract}

Keywords: cognition, an individual's cognitive activity, cognitive action.

Introduction. Against the background of scientificand-technological advance, when the subjective facilitation's role for building up our society is noticeably increasing, the problem of a person's activity formation is one of the most actual in pedagogical theory and practice of higher educational institutions. After all, an individual's purposeful conscious activity changes the environment, affecting economic, political, inner features of the society development. These processes determine a person's activity in learning, as his/her cognitive activity formation correlates to autonomy, initiative, integrity, willpower and other human traits development. Thus, while training a specialist in tax matters not only professional knowledge and skills shaping should be provided but also building up a true citizen of an independent Ukrainian state developing, shaping his/her cognitive needs and inducements for further independent knowledge acquisition and skills upgrading should be ensured. 
Research aim is to study the aspects of cognitive activity in history retrospective.

Materials and methods. To achieve the aim and solve research tasks the appropriate, to the authors' opinion, methods are used. They are theoretical psycho-pedagogic literature analysis to define the stateof-arts of the problem in pedagogy theory and practice; analysis, synthesis, abstracting, compilation for studying the cognitive action aspects, and its activity in the history retrospective. The researchers' works analysis proclaims the introduction of terms "knowledge", "cognitive strength", "cognitive activity" in pedagogical science while studying the phenomena of learning, training, training activities. The researchers of didactics problems, assuming that the learning process is the highest form of human activity, aimed at identifying new patterns nature and society movement, new knowledge on nature and social phenomena establishing, showed that in the training process the digestion of prior-gained knowledge about nature, society takes place. In this regard, new terms "cognitive activity" and "training activity" were introduced.

Results and discussions. It should be noted that the content of students' cognitive activity cannot be compared with the content of a scientist's cognitive activity. Therefore, on the one hand, to define the concepts of "cognitive activity" and "training activity", and on the other - to show their dialectical relationship we accept the concept of "training-and-cognitive activity" in the following study. Scientific studies are becoming more complex, more diverse, and their impact cannot depend on cognitive process thoroughness, its common factors and features use. "Guiding knowledge to yourself" inevitably extends epistemology and gnosiology possibilities (Pugach, 1985).

Scientific knowledge has its historically altered morphology. Its science's historical path analysis makes it possible to argue that its origins come from ancient philosophical schools, philosophers of Ancient India, China, Egypt, the countries of Mesopotamia. Understanding the world knowledge and ideas development is especially native to the epic of antiquity. In those times philosophers' doctrines (Heraclius Ephesus, Democrat, Confucius, Socrates, Plato, Aristotle) the orienting ideas for researchers in the most difficult life manifestations for following centuries were embraced. These manifestations feelings, memory and imagination images, associations, passion and individual differences between people (temperament) - were deduced from the action of external objects on the organic body and from the material processes - in the middle of it.

Of particular importance was Aristotle theory. It combined determinism with systematicity principles and psychological knowledge categories. The approach, nowadays called systematic, determined the structure a great Greek's thinking. In his theory the determinism, systematicity and development are indivisible. So, despite the fact that the problem of cognitive activity in the ancient philosophers is not thoroughly covered, yet there are very interesting thoughts about its role in cognition in some scholars' works.

In the Middle Ages education the science was scholastic in nature and separated from life. Only in the Renaissance era, when new philosophical schools were formed, "a person became the first principle of being" (Galuzinskyi, 1995, p. 7), the humanitarian education began to develop rapidly. The bright representative of the humanists was Yan Amos Komenskyi. Based on his sensualist epistemology, he considered the main task of a teacher to develop a student's senses, speech and primary hands-on skills. At the same time, Komenskyi paid great attention to the disclosure of causative relationship between the surrounding world phenomena and taught the students to analyze them. In "Great didactics" he noted that a person should be a wise creature; she has "... to explore everything and name and count everything or know and be able to name and understand everything that exists in the world ..." (Komenskyi, 1982, p. 283).

An outstanding scientist, philosopher, founder of the New times experimental science was the Englishman Francis Bacon, who proclaimed the purpose and essence of studying of the laws of nature, understanding independent isolated things and their properties. Human knowledge, according to Bacon, is capable to reveal the secrets of nature and master it in that way. He was able to study the cognitive ability, its possibilities, proclaiming the experience as the only source of human knowledge. It is Bacon, studying the problems of cognitive activity, drew the attention to the subjective moments of knowledge and even tried to classify them (Pugach, 1985).

Bacon's follower, the English philosophermaterialist John Locke, developed the doctrine on experience-based knowledge origin. Locke, like other empirical philosophers, considered the activity of thinking limited. In this regard, the cognition method, developed by them, turned into a combination of methods for building a complex to a simple.

A similar approach to Bacon's and Locke's views is found in the theories of the French materialists Y. Lametry, D. Diderot, K. Helvetius, P. Gelbach. But among the materialists there were also rationalists who, in terms of developing the problem of cognitive activity, interpreted cognition as a reality reflection in human consciousness; while appreciating the role of sensory experience. Explaining the cognition as a 
process that does not require a qualitative transformation of the source data, the rationalists did not consider the cognitive activity as a problem.

The impact to knowledge theory was made by idealist philosophers of the late XVIII and early XIX centuries. Kant, Fitch, Schelling, and Hegel opposed the old materialism, holding that against underestimating the cognition activity, in the contemplation drift. The cognition is interpreted by German philosophers much wider, it is studied not only in relation to natural subjects, but also in its links with social, ethical and aesthetic phenomena. It was I. Kant who first raised the issue of cognition activity as an epistemological problem. According to Kant, a person's cognitive abilities are manifested in the special forms that subordinate and organize the knowledge content:

Thus, if the old materialists had the dependence of thinking on feelings as the object of the study, then Kant focused his attention on sensory visual representations dependence form the "pure" priori forms of mind (Bendasiuk, 1997, p. 189).

In his works I. Fitkhe considered only the essence of knowledge. At the same time, he considered the feeling was not a reflection of reality, but a product of a subject's creativity. The cognition process is considered by Fitkhe as the process of creating reality and activity as the basis of knowledge (Kornilov, 1989).

The principle of knowledge activity and effectiveness was thoroughly investigated by G. Hegel. His "Absolute Idea" is not only about thinking, but about being. The cognition in Hegel's theory is represented as self-education (self-development) of "absolute idea". Comparing Kant and Fitkhe, the problem of cognitive activity is considered by Hegel more thoroughly. For the first time in history, he introduced the element of practice into cognition theory. Hegel analyzed the cognition as active human activity, introduced into the process of social history, in interrelation with other forms of activity (Bim-Bad, 1986).

The search for ways to overcome the difficulties in education system development in Ukraine makes us turn to the study and analysis the Ukrainian educators' heritage while formatting and strengthening the power of the Middle-Age East-Slavic state.

Domestic culture saving and development, education growth, people's national and religious interests protection as the directions of reformist ideology were incidental to cultural and educational centres of that time. The ideological struggle against theocracy of Catholic ideology was led by brotherhoods as centres for national culture and people's cultural values protection. Thanks to brethren schools network system the education and patriotic literature was growing, the Orthodoxy was strengthening as a means of fighting against the colonial policy of the Polish gentry and the Catholic clergy. The most significant contributions to these processes were made by Lviv, Kyiv and Lutsk brethren schools.

The prominent educators of that time were Professors Petro Mohyla, Joseph KononovichGorbatskyi, Innocentiy Hisel, Ionikiy Galyatovskyi, Lazar Baranovych, Stefan Yavorskyi, Theophan Prokopovych, Georgy Shcherbytskyi, Heorhiy Konyskyi and others (Khyzhniak, 1988).

P. Mohyla, in his own works, preached ascetic ideals, self-knowledge, moral self-perfection, unity with God. The Professor of Philosophy I. KononovychGorbatskyi acknowledged the objectivity of the world and its cognition, shared the basic doctrine of sensualism that knowledge began with experience and sensations. In his theory, the main role belongs to the human intelligence. The professor pointed out the path to the knowledge of God through the cognitive activity of mind. The theory of cognition by S. Yavorskyi is based on the principles of I. Hisel's doctrine. By approving sensational ideas, he admits the possibility of mind existence regardless sensory datum, brain, body, and believes that logic as science manages human mind actions, emphasizing the greatness, power, independence and activity of a man.

Explaining the theory of cognition for students, Professor H. Konyskyi emphasized the infinite possibilities of a man in learning the world and himself. At the heart of knowledge lies the mind: true only that which is proved and comprehended by reason. Professors of the Kyiv-Mohyla Academy made a significant contribution to the theory of knowledge, contributing to the development of scientific thought on the Ukrainian soil of medieval scholasticism, the Renaissance and Enlightenment.

Graduates from the Academy H. Skovoroda and M. Lomonosov were the speakers of advanced progressive ideas that contributed to the formation of a way of vision and comprehension of the world. Promoting the problem of self-knowledge of a man, H. Skovoroda emphasizes that knowing himself means to know the logic of the universe, to understand God in himself. The role of science and education, according to $\mathrm{M}$. Lomonosov, is based on the materialist worldview, it was not a recipe for learning: in their synthesis, they were quite a logical, scientific, complete picture. Innovative pedagogical ideas of $\mathrm{M}$. Lomonosov were designed to create favourable conditions for the formation and development of cognitive abilities of students. Educational significance of his legacy is in a progressive, democratic, humanistic approach to education (Prokofiev, 1986, p. 85). 
One of the most famous thinkers of that time was Jacob Kozelskyi. The most important problems of epistemology, psychology, logic, social philosophy are represented in the original work "Philosophical sentences" (Shpet, 1989). Y. Kozelskyi believed that human knowledge begins with the senses; it is they who give an impression to the soul. At the highest level, knowledge is characterized by logical thinking, inherent only to a man. At the sensory level, certain properties of things are learned, at the highest - the essence of things, the process and patterns of their development.

The study of cognitive activity is devoted to a significant part of the scientific work of P. Lodia professor of Lviv University. In addition to the adaptation of Western European educational ideas in the Ukrainian spiritual culture, he directed his efforts to study questions of the theory of cognition and logic (Gorskyi, 1996).

The philosophical credo of M. Hohol is romantic perception of the world. He considered the meaning of human life is in life itself. And there is no other purpose for a person than real existence (Philosophy, 1995). The essence of M. Hohol's creative quest was manifested in the rout to knowing the spiritual essence of a man. The idea of "education" of the soul, he contrasted with commitments to human intelligence improvement.

The nineteenth century was marked by enlightenment movement with the main feature to reach common literacy. K. Ushynskyi's knowledge doctrine grounds basis of materialist dialectics and the doctrine on feeling and will lays the basis of the materialist theory for upbringing (Ushynskiyi, 1945).

In the centre of Taras Shevchenko's ideas - a person, his/her life destiny, "... natural inalienable rights inherited from free and heroic ancestors, inseparability of labour and humanity, freedom and social justice" (Philosophy, 1995, p. 147). T. Shevchenko's achievements clearly testify to the high level of his inner needs, clearly defined ideological orientation, and high aesthetic qualities. T. Shevchenko's worldview ideas became crucial for his followers, inspiring them to civic service to Ukraine.

Kyiv is the most prominent centre for enlightenment in the mid-XIX century. Thinkers, striving to combine the ideas of enlightenment and romanticism, note the role of feelings, human experiences in the inner activity of a person. A famous figure among the Kyiv Philosophical School representatives was P. Yurkevych. His study was directed to morality area. Investigating the process of cognition, he believed that this process is carried out in three forms: 1) knowledge through representation; 2) knowledge through concepts; 3) knowledge through the idea.
Mykola Kostomarov, Panteleimon Kulish, Oleksandr Potebnia, Mykhaylo Drahomanov and other intellectuals of Ukraine made a significant contribution to new intellectual culture development based on reality comprehension, social and political life analysis. M. Kostomarov made a significant contribution to theoretical substantiation of the Ukrainian idea philosophy, according to which the main content and direction of the historical process is determined by the people.

At the heart of O. Potebnia's provisions on a person's cognitive activity there is language and thinking interrelation (Philosophy, 1995).

The creative legacy of the prominent philosopher, sociologist, historian, and publicist M. Drahomanov concerns a matter of Ukrainian cultural life various branches. The determinism he defines in the only reliable way to explain the phenomena. According to him, the highest value is a person, and the highest criterion is the idea of justice (Drahomanov, 1991).

The main direction of education development in Ukraine at the end of XIX and early XVIII centuries identified leading tendencies common to new generation of national conscious intellectuals. Prominent thinkers and socio-political figures of that time were Volodymyr Lysevych, Ivan Franko, Lesia Ukrainka, Volodymyr Vernadsky, Mykhailo Hrushevskyi, Volodymyr Vynnychenko and others.

Relying on positive knowledge, V. Lysevych's philosophy does not deny the active role of the subject while cognition. The main object of I. Franko's and Lesia Ukrainka's philosophy was a person in his/her unity with nature, the meaning of his/her life, his/her uniqueness, consciousness and dignity. The views of these artists are echoed in that the purpose of knowledge to come to the truth (veritas). The veritas, according to I. Franko, is the unity of cognition and practical activity methods. I. Franko's and Lesia Ukrainka's sense of global consciousness marked the peak of a person's philosophical comprehension of the world through the spiritual-figurative disclosure of social life contradictions (Philosophy, 1995.). Their artistic heritage, along with journalistic and scientific works, enriched the Ukrainian spiritual culture by its content, deepening the development of a person's cognitive activity problem as an independent component of educational thought.

As a thinker-scholar, V. Vernadskyi was in that advanced of his time that only now the one can appreciate the genius of his achievements and scientific predictions. The scholar initiated the holistic philosophy of the universe, was one of the anthropocosmism founders as a system that unites the harmonious whole of the natural-historical and sociohumanitarian tendencies of science development (Vernadskyi, 1988). At the heart of the thinker's 
philosophical worldview is the belief in the power of a person's activity, in his/her mind.

Among of the Ukrainian intellectuals representatives in the first decades of the XX century the special place belongs to M. Hrushevskyi and V. Vynnychenko. M. Hrushevskyi's historical concept represented in 2000 scientific publications on problems of culture, history, education and based on the principles of systematicity, unity, consistency, historical and logical in knowledge. The basis of the scientist's approaches to the knowledge of the historical process - the requirement to follow not priori conclusions from the eternal and unchangeable principles of human thinking, but inductive search on the basis of factors that take into account the biological, economic and, above all, mental factors (Hrushevskyi, 1993).

From the position of development of the problem of cognitive activity V. Vynnychenko confessed that the direction of philosophical ideas should be based on searching human happiness (Vynnychenko, 1990). Conceptual approaches of the artist to society development testify that people are the main driving force.

The rise of spiritual life is celebrated in the 30 s of XX century. Being in the market for "actual" questions of historical and dialectical materialism Ukrainian researchers work on the problems of sociology, logic, and psychology. Despite all the prohibitions the philosophical views of H. Skovoroda, professors of the Kyiv-Mohyla Academy, philosophical and sociopolitical ideas of the Cyril-Methodius Society, figures of the Ostroh Scientific and Educational Centre were studied. The early socialist period of Ukraine is characterized by constant discussions, polemics of scientists about methods and forms of understanding the world, its essence of historical development, main driving forces, and so on. There was real confrontation between the orientations of "Moscow" official institutions and the cognitive interests of Ukrainian researchers.

Modern scientific thought should redefine the scientific heritage of outstanding scholars, thinkers, and figures of this period: the M. Khvylovyi, M. Skrypnyk, D. Dontsov, A. Makarenko, V. Lypinskyi, V. Yurynets, D. Chizhevskyi, O Olzhych (Kandyba), I. Mirchuk, P. Kopin, V. Sukhomlynskyi and others, objectively shown their contribution to cognitive problems development, of spiritual revival issues for the Ukrainians.

During the 70 's and 80 's there is a change in the emphasis of philosophical searches vector; there is a step away the problems of dialectical materialism to expanding ideological themes. The new problems of worldview formation, its connection with scientific knowledge, a man and nature interaction, methodology, the world creation etc. are explored.

From the standpoint of modern philosophical approaches, the result of any knowledge is the image as an ideal generalization of an object's essential relations. There are sensory and rational cognition where the sensory knowledge is primary. There are three forms of sensory knowledge: sensation, perception and presentation. With the help of a person's senses only certain properties of objects, phenomena are known. On the basis of sensations perception is formed - the integral reproduction of the object. As a result of repeated perception of an object, the consciousness of a person can hold him in memory, and if necessary, reproduce a generalized image. Representation - a generalized image of an object, perceived before. In general, forms of sensory knowledge reproduce the object in a figurative form (Philosophy, 1995).

Rational knowledge, in contrast to the sensory, penetrates into the essence of objects, phenomena, processes. In the same way as forms of rational cognition, distinguish concepts, judgments and inference. Usually, concepts are defined as one of the main forms of reality reflection on the level of abstract thinking, they enable to distinguish those qualities of an object that cannot be pictured via an image.

Modern cognition theory considers judgment as a process where our knowledge is shaped, changed and evolved. The combination of several judgments forms an inference. This form of rational knowledge gives an indirect and generalized idea of reality and its reflection in human consciousness. The ability to make the inference is a sign of a person's intellectual growth. It is important for solving the activity problem the ability of making inferences is improved as a result of education and upbringing. Naturally, in cognitive practice, one cannot absolve sensory or rational forms of knowledge: only combination of these forms phenomena and processes essence knowledge can make for veritas.

Conclusions. Consequently, the effectiveness of studying students' educational and cognitive activity depends on how thoroughly the cognitive process is studied, the way its laws and features are used. Taking into account the possibilities of the cognition theory, its Klondike was set in the Ancient world era and filled with new content rising to a new level in each generation, allows to predict the problem studying vector and put forward the hypothetical predictions of its solution.

Prospects for further research may be related to psychological and pedagogical conditions studying for educational process improvement by means of activating students' cognitive activity. 


\section{List of references}

Бендасюк, С.П., 1997. Педагогічні погляди І. Канта. Педагогіка і психологія, 3, с. 184-189. 124.

Бим-Бад, Б.М., 1986. Педагогические идеи в ранних произведениях Гегеля. Советская педагогика, 7, с. 121-

Вернадский, В.И., 1988. Философские мысли натуралиста. Москва: Наука.

Винниченко, В.К., 1990. Відродження нації: У 3 т. Т.1. Київ: Політвидав України.

Галузинський, В.М. та Євтух, М.Б., 1995. Основи педагогіки та психологї̈ вищої школи в Украӥні. Київ : ІНТЕЛ.

Горбач, Н.Я., ред. Філософія: підручник, 1995. Львів: Логос, 1995.

Горський, В.С., 1996. Історія украӥнської філософії: курс лекцій. Київ : Наукова думка.

Грушевський, М.С., 1993. Історія України, приладжена до програми вищих початкових шкіл і нижчих класів шкіл середніх. - Київ: Варта.

Драгоманов, М.П., 1991. Про українських козаків, татар та турків. 3 додатком про життя Михайла Драгоманова. Київ: Дніпро. 476.

Коменский, Я.А., 1982. Великая дидактика. В: Избранные пед. соч.: в 2-х т. Т.1. Москва: Педагогика, с. $242-$

Корнилов, С.В., 1989. Кантовское обоснование педагогики. Советская педагогика, 11, с. 122-126.

Прокофьев, М.А., 1986 Великий ученый, пламенный патриот. Советская педагогика, 10, с. 81-86.

Пугач, Г.В., 1985. Познавательная активность человека. Москва : Изд-во полит. литературы.

Ушинский, К.Д., 1945. Родное слово. В: Избранные пед. соч. Москва: Гос. уч. пед. узд. Наркомпросса РСФСР. С.204-217.

Хижняк, 3.И., 1988. Киево-Могилянская академія. Київ: Вища школа.

Шпет, Г., 1989. Очерк розвития русской философии. В: Сочинения. Москва: Мысль. С.122-129.

\section{Translated \& Transliterated}

Bendasiuk, S.P., 1997. Pedahohichni pohliady I.Kanta. [Pedagogical views of I.Kanta.] Pedahohika i psykholohiia [Pedagogy and psychology], 3, s. 184-189, [in Ukrainian].

Bym-Bad, B.M., 1986. Pedahohycheskye ydey v rannykh proyzvedenyiakh Hehelia [Pedagogical ideas in the early works of Hegel]. Sovetskaia pedahohika [Soviet pedagogy], 7, s. 121-124, [in Russian].

Vernadskiy, V.I., 1988. Filosofskie myisli naturalista [Philosophical thoughts of the naturalist]. Moskva: Nauka [Science], [in Russian].

Vynnychenko, V.K., 1990. Vidrodzhennia natsii [Revival of the nation]: U 3 t. T.1. Kyiv: Politvydav Ukrainy [Political Publishing House of Ukraine], [in Ukrainian].

Haluzynskyi, V.M. ta Yevtukh M.B., 1995. Osnovy pedahohiky ta psykholohii vyshchoi shkolyv Ukraini [Fundamentals of Pedagogy and Psychology of Higher Education in Ukraine]. Kyiv: INTEL [INTEL], [in Ukrainian].

Horbach, N.Ia., 1995. red. Filosofiia [Philosophy]: pidruchnyk, Lviv: Lohos [Logos], [in Ukrainian].

Horskyi, V.S., 1996. Istoriia ukrainskoi filosofii: kurs lektsii [History of Ukrainian philosophy: course of lectures]. Kyiv: Naukova dumka [Scientific thought], [in Ukrainian].

Hrushevskyi, M.S., 1993. Istoriia Ukrainy, pryladzhena do prohramy vyshchykh pochatkovykh shkil i nyzhchykh klasiv shkil serednikh [History of Ukraine, attached to the program of higher elementary schools and lower classes of secondary schools]. Kyiv: Varta [Warding], [in Ukrainian].

Drahomanov, M.P., 1991. Pro ukrainskykh kozakiv, tatar ta turkiv. Z dodatkom pro zhyttia Mykhaila Drahomanova [About Ukrainian Cossacks, Tatars and Turks. With the addition of Mikhail Drahomanov's life]. Kyiv: Dnipro [Dnieper], [in Ukrainian].

Komenskyi, Ya.A., 1982. Velykaia dydaktyka. V: Izbrannyie ped. soch. [Great Didactics. Selected pedagogical works]: v 2-kh t. T.1. Moskva: Pedahohyka [Pedagogy], s.242-476, [in Russian].

Kornylov, S.V., 1989. Kantovskoe obosnovanie pedagogiki [Kantian substantiation of pedagogy]. Sovetskaia pedahohyka [Soviet pedagogy], 11, s. 122-126, [in Russian].

Prokofev, M.A., 1986 Velikiy uchenyiy, plamennyiy patriot [Great scientist, flaming patriot]. Sovetskaya pedagogika [Soviet pedagogy], 10, s. 81-86, [in Russian].

Puhach, H.V., 1985. Poznavatelnaya aktivnost cheloveka [Cognitive activity of a person]. Moskva: Yzd-vo polyt. literaturyi [Publishing house of political literature], [in Russian].

Ushynskyi, K.D., 1945. Rodnoe slovo. V: Izbrannyie ped. soch [Native word Selected pedagogical works]. Moskva: Hos. uch. ped. uzd. Narkomprossa RSFSR [State institution is a pedagogical publication of the People's Commissariat of the RSFSR], s. 204-217, [in Russian].

Khyzhniak, Z.Y., 1988. Kyevo-Mohylianskaia akademiia [Kyiv Mohyla Academy]. Kyiv: Vyshcha shkola [Higher school], [in Ukrainian].

Shpet, H., 1989. Ocherk razvitiya russkoy filosofii [Essay on the development of Russian philosophy]. V: Sochineniya [Compositions]. Moskva: Myisl [Thought], s. 122-129, [in Ukrainian]. 


\section{Проблема пізнавальної активності особистості в історичній ретроспективі}

\section{Інна Зайцева ${ }^{1}$, Тетяна Пащенко르, Петро Лузан ${ }^{3}$,}

1 кандидат технічних наук, доцент кафедри журналістики, української філології та культури Національного університету державної фіскальної служби України

2 кандидат педагогічних наук, старший науковий співробітник, старший науковий співробітник лабораторії науковометодичного супроводу підготовки фахівців у коледжах і технікумах Інституту професійно-технічної освіти НАПН України, м. Київ

3 доктор педагогічних наук, професор, головний науковий співробітник лабораторії науково-методичного супроводу підготовки фахівців у коледжах і технікумах Інституту професійно-технічної освіти НАПН України, м. Київ

Реферат. У статті досліджуються аспекти пізнавальної діяльності, активності в історичній ретроспективі. Пізнання і його вивчення не є незмінним, раз і назавжди даним, а являє собою щось, що розвивається за визначеними законами. Воно має довгу історію, джерела якої ведуть у найдревнішу філософію. На кожному етапі свого розвитку знання - це підсумок історії пізнання, сутність всіх форм людської діяльності. Наукове пізнання має свою історично змінювану морфологію. Аналіз історичного шляху цієї науки дає можливість стверджувати, що їі витоки беруть свій початок від стародавніх філософських шкіл, філософів Стародавньої Індії, Китаю, Сгипту, країн Месопотамії. Феномен пізнавальної активності особистості є складним і багатоаспектним. Учені стверджують, що пізнавальна діяльність являє собою складний процес переходу від незнання до знання, від невміння до вміння, від випадкових спостережень до систематизованого пізнання матеріального світу, до оволодіння науковими істинами. При цьому людина, опановуючи нові знання, впливає на світ, який, у свою чергу, змінює людське життя. У статті проведений аналіз впливу історичних умов на розвиток наукової думки про пізнання, пізнавальну активність. Результативність вивчення навчально-пізнавальної активності студентів залежить від того, наскільки грунтовно досліджено пізнавальний процес, як використовуються його закономірності й особливості. Автором акцентовано, що врахування можливостей теорії пізнання, невичерпні джерела якої започатковуються ще в епоху античності, наповнюються новим змістом та підносяться на новий рівень кожним поколінням, що дає змогу спрогнозувати напрям дослідження проблеми і висунути гіпотетичні передбачення її вирішення.

Ключові слова: пізнання, пізнавальна активність, пізнавальна діяльність. 